\title{
RELATIONSHIPS OF SERVICE QUALITY, SERVICE VALUE AND CUSTOMER LOYALTY - A STUDY OF DOMESTIC AIRLINE SERVICE
}

\author{
Tran Thị Phuong Thao, Pham Ngoc Thuy \\ University of Technology, VNU-HCM \\ (Manuscript Received on April 04 ${ }^{\text {th }}$, 2011, Manuscript Revised September $21^{\text {st }}$, 2011)
}

\begin{abstract}
For several decades, improving service quality has been considered the best way to enhance customer satisfaction that leads to increase customer loyalty. However, customer satisfaction that is viewed as the most important factor to determine customer loyalty, does not always lead to success. Moving marketing from customer satisfaction orientation to customer value orientation has recently been being a central issue in service marketing. Given these situations, this study aims to explore the relationships between service quality, service value and customer loyalty. Its purpose is to test whether service value should be an alternative to determine customer loyalty beside customer satisfaction. Results of SEM analysis based on a sample of 308 passengers using airlines service in Ho Chi Minh City show that there are two factors of service quality with significantly positive impacts on customer loyalty through such an intermediary as service value.
\end{abstract}

Key words: Service quality, service value, customer loyalty, domestic airline service, Vietnam.

\section{INTRODUCTION}

Nowadays, providing superior values of service to customers is viewed as the best way to gain competitive advantages in business world (Woodruff, 1997). Service value is known as a critical factor that affects a customer's decision-making process (Rust and Oliver, 1994; Sweeney et al., 1999). Heskett et al. (1994) and Jen \& Hu (2003) indicated that service value is very important factor in differentiating a firm's service to others. In addition, following the S-D logic perspective (Vargo and Lusch, 2004), some scholars stated that service and value are viewed as two logically inseparable concepts which qualify as candidates for the title as the preeminent marketing concept (Gronroos, 2008; Babin and James, 2010). Thus, creation of customer value becomes an important topic that takes many scholars' attention. Some of them even suggested moving marketing away from a focus on creating customer satisfaction to creating customer value (Ngo and O'Cass, 2010). However, there are few studies that investigate the antecedents and the consequences of service value (Cronin et al., 2000; Sweeney et al., 1999).

On the other hand, for the last three decades, researchers and practitioners have made their efforts to determine the key role of service quality to customer purchase behaviors; their recommendations help providers give services meet customer expectations. Therefore, service quality is an important element to contribute to essential strategy for success and survival in competitive environment (Blackwell et al., 2001; Kotler, 2000), if the quality of services is not valued, it only remains the quality. However, if quality is valued, then it becomes the value. This value helps to determine the strength and direction of the relationship that exists between a particular service and a specific customer (Frondizi, 1997). In the purchasing process, customers encode their perceptions of value as synopsis of relevant service information, and purchase service based on their assessment of this information. Enhancing value is a strategy that companies need to emphasize (Kashyap and Bojanic, 2000), but few empirical studies have done to address the effect of service quality on service value (Gallarza and Saura, 2006). Therefore, this study aims to empirically test the relationships of service quality and service value in customer post purchase process, i.e. customer loyalty.

The empirical setting of this research is domestic airline services in the transition economy of Vietnam. During recent years, Vietnamese airlines industry has developed quickly with various brands participating in this market. To sustain competitive advantage, an appropriate strategy to attract and retain their customers should be developed. This study has a hope to provide a better 
understanding of customer's behaviors to marketers in domestic airlines industry.

\section{LITERATURE BACKGROUND AND HYPOTHESES}

\subsection{Service quality}

Service quality is an important issue in service management. Many studies have been undertaken to understand and identify this construct in the last three decades. However, conceptualization and measurement of service quality perceptions have been controversial topics in service marketing literature until now. Two main dominant schools of service quality perceptions which researchers have generally adopted are the Nordic school (Gronroos 1982, 1984) and the American School (Parasuraman, Zeithaml, and Berry 1988). The first school posed that service quality stemed from the comparison of perceived service quality with expected service quality. Service quality consists of two dimensions, i.e. functional and technical quality (Gronroos 1982, 1984). Technical quality or service outcome quality represents the information of whether the service meets customers' expectations; functional quality or service process quality refers to the customers' perceptions of interactions that happen during service delivery process. The second perspective defined service quality as the gap between customer's normative expectations for the service with their perceptions of the service performance (Parasuraman, Zeithaml, and Berry, 1988). These authors provided a measurement named SERVQUAL, with five dimensions: tangibles, reliability, responsiveness, assurances and empathy. SERVQUAL measurement has been widely cited by many scholars in service marketing literature and used quite widespread in many industries (Brown et al., 1993). Nevertheless, this measurement has also been subject to criticism (Asubonteng et al., 1996) because of only focusing on the service delivery process and neglecting the service encounter outcomes (Gronroos, 1990); lacking validity of the model, particularly the dependence or independence of the five dimensions (Babakus and Boller, 1992; Cronin and Taylor, 1992). Therefore, this study follows the Nordic school to investigate service quality based on two dimensions, service outcome and service process.

\subsection{Service value}

Service value has been judged to be one of the most important elements of differentiation in service marketing strategies (Jen and $\mathrm{Hu}$, 2003) and is considered as a significant factor in consumer decision making process (Sweeney et al., 1999). Zeithaml (1998) defined perceived value is the customer's overall assessment of the utility of a service based on what is given and received. Service value of the same service offered might be perceived differently by different customers. For what is received, some customers focus on service quality, others need more convenient in using service. For what is given, some are concerned with their payment, others focus on their time and efforts. Based on trade-off principle of Zeithaml (1988) and the process outcome approach that is used to conceptualize the service value in this study has its root in Gronroos (2001), the measurement scale of service value in this study is divided by two interrelated components, namely process value (or functional value) and outcome value (or technical value). This conceptualization was also supported by Babin et al (1994) who suggested a bi-dimensional representation of value.

2.3 Relationship between service quality and customer loyalty

Loyalty is defined as "a deeply held commitment to rebuy or repatronize a preferred product/service consistently in the future, thereby causing repetitive same-brand or same brand-set purchasing, despite situational influences and marketing efforts having the potential to cause switching behavior" (Oliver, 1999, p. 34). Customer loyalty is considered as an important indicator of the likely success of a business (Butcher et al., 2001; Oliver, 1999). Customers who are loyal with a firm tend to repurchase and/or say good thing about it. Although, there is no general theoretical framework covering all aspects of customer loyalty, many researchers and practitioners believe that service quality is an antecedent of loyalty (Gremler and Brown, 1997). Previous research findings support the positive influence of service quality on customer loyalty (Cronin et al., 2000; Parasuraman and Grewal, 2000; Zeithaml et al., 1996). However, the precise loyalty implications of service quality are still 
unresolved and vary across industries (Cronin et al., 2000). While Boulding et al. (1993) found the positive relationship between service quality and repurchase intentions and willingness to recommend, the study by Cronin and Taylor (1992) showed that there was no relationship between service quality and repurchase intentions. The result of Lee and Cunningham's (1996) research in airline industry demonstrated that service quality positively correlated with customer loyalty. Given this diversifying results, this studies proposes and test the relationship between the service quality and loyalty:

H1. There is a positive impact of service quality on customer loyalty towards a service.

2.4 Relationship between service quality and service value

Zeithaml (1988) indicates that there is a positive impact of service quality on the perceived value, and correlates positively with purchasing decisions. With the emerging of SD logic perspective (Vargo and Lusch, 2004), many researcher consider value as a core element in market exchange; service and value are two logically inseparable concepts which qualify as candidates for the title as the preeminent marketing concept (Gronroos, 2008; Babin and James, 2010). Thus, creation of customer value becomes an important topic that takes many scholars' attention. Some marketing scholars even suggest to change from creating customer satisfaction to creating customer value (Ngo and O'Cass, 2010). Frondizi (1997) argues that if the quality of service is valued, then it becomes the value which helps to determine the relationship between a particular service and a specific customer. Although, the impact of service quality on service value is increasingly discussed in marketing service (Lee et al., 2005), few empirical studies have done to address this relationship (Gallarza and Saura, 2006). Given these above situations, it is proposed that:

$\mathrm{H} 2$ : There is a positive impact of service quality on service value.

2.5 Relationship between service value and customer loyalty

Loyalty is strongly linked to customer value which is a major contributor to purchase intention (Chang and Wildt, 1994). Customers stay with a provider as long as it offers them superior value compared to others (Khalifa, 2004). Based on the cognitive-based perspective of the value construct, some authors posit a direct impact of customer value on behavioral outcome, neglecting the role of satisfaction (Zeithaml, 1988). Customer value is a significant antecedent of loyalty while customer satisfaction is not (Gan et al., 2006). The critical role of service value toward customer loyalty has been mentioned by many empirical studies (Bolton and Drew, 1991; Sirdeshmukh et al., 2002). However, there is no general theoretical framework covering all aspects of customer loyalty (Shan et al., 2003), many scholars indicated that antecedents of customer loyalty are service quality customer satisfaction (Cronin et al., 2000; Parasuraman and Grewal, 2000; Zeithaml et al., 1996). Given this diversifying results, this study proposes and test the relationship between the service value and loyalty:

H3. There is a positive impact of service value on customer loyalty towards a service.

\section{METHODOLOGY}

The model and hypotheses are tested by using the data collected fromVietnamese passengers who have used domestic airline services within 6 months. The survey was conducted by using convenience sampling method with a structured questionnaire. The scales measuring the constructs in the model were adopted from previous studies with necessary adjustments to accommodate the particular empirical research context (i.e. domestic airlines services). Measurement scales for the two dimensions of service quality were adjusted from Gronroos' scales (1982). A customer loyalty scale was adopted from Zeithaml et al. (1996). Measurement scales for the two components of service value were adjusted from those developed by Zeithaml (1988). These scales (see Table 1), which were translated into Vietnamese using a translated and back-translated procedure, are five Likert type. The two translators were university academics who are fluent in both languages.

\section{RESULTS}

A total of 308 usable questionnaires are obtained and used for this study. Data 
collection method is convenient sampling with face-to-face interviews using a structured questionnaire. This sample consists of $55.5 \%$ male and $45.5 \%$ female passengers on three domestic airlines operating in Vietnam (Vietnam Airlines, Jetstar Airlines and Mekong Airlines). The age group of 18-25 accounts for $30.8 \%$, of $26-35$ is of $35.4 \%$, and $33.7 \%$ are above 35 of age. The monthly incomes of the respondents which lower than 5 million VND accounts for $51.3 \%$ and $48.7 \%$ are above 5 million VND. About $68.8 \%$ of the respondents have flied at least twice a year. The majority $(69.7 \%)$ of the respondents pay air ticket fees by their own money, the rest get money from their bosses.

Exploratory factor analysis (EFA) was first employed to have preliminary indications of unidimensionality, and construct validity. This procedure was carried out in two stages, the first was on the individual scales and the second was on all scales combined. The results showed that 1 out of 22 items were eliminated from the original scales due to low loading. Then confirmatory factor analysis (CFA) was conducted, using AMOS software program (Arbuckle and Wothke, 1999), on the full measurement model which represent relations among all constructs and related items. CFA results showed that 4 out of 21 items were eliminated due to high covariance of error terms. The model fit indices of the full measurement model with the remaining 17 items are as follows: Chi-square $=160.726$; $\mathrm{dF}=109 ; \quad \mathrm{p}=0.001 ; \quad$ Chi-square $/ \mathrm{dF}=1.475$; $\mathrm{GFI}=0.943 ; \quad \mathrm{TLI}=0.965 ; \quad \mathrm{CFI}=0.972$; RMSEA $=0.039$. The HOETLER index of 257 is above the threshold value of 200 which indicates that the sample size is large enough for the analysis (Byrne, 2001). Consequently, the full measurement model fits the data set in this empirical study. The results (Table 1) showed factor loadings of all items on their designate constructs which range from 0.627 to 0.830 , indicating satisfactory level of convergent validity (Hair et al., 2006). The correlations between constructs ranged from 0.356 to 0.602 which were lower than 0.85 , meaning that discriminant validity of all scales were achieved (Kline, 2005). The composite reliabilities for constructs ranged from 0.704 to 0.832. Generally, the results of CFA indicated that all measurement scales achieved reliability, convergent and discriminate validity.

The structural model was then tested using maximum likelihood (ML) estimation. The results of SEM indicated in a good fit between the model and data: Chi-square $=173.693$, $\mathrm{df}=113, \quad \mathrm{p}=0.000, \quad$ Chi-square $/ \mathrm{df}=1.537$, GFI $=0.938, \quad$ TLI $=0.960, \quad$ CFI $=0.967$, RMSEA $=0.042$.

Table 1. Scale items for all constructs

\begin{tabular}{|c|c|c|}
\hline Item wording & Std. loading & Comp. reliability \\
\hline \multicolumn{3}{|l|}{ Outcome quality } \\
\hline $\mathrm{X}$ provides the services that customers want & 0.661 & \multirow{3}{*}{0.759} \\
\hline $\mathrm{X}$ knows the kind of services its customers are looking for & 0.749 & \\
\hline $\mathrm{X}$ knows the quality of services its customers need & 0.734 & \\
\hline \multicolumn{3}{|l|}{ Process quality } \\
\hline I feel good about what $\mathrm{X}$ provides to me & 0.805 & \multirow{2}{*}{0.704} \\
\hline Overall, I would say X provides excellent service & 0.668 & \\
\hline \multicolumn{3}{|l|}{ Outcome value } \\
\hline \multicolumn{3}{|l|}{ In comparison with the money, time and effort I spend... } \\
\hline The services I receive from $\mathrm{X}$ is good & 0.673 & \multirow{4}{*}{0.776} \\
\hline The services I receive from $\mathrm{X}$ is reasonable & 0.701 & \\
\hline $\mathrm{X}$ provides me with the benefits I want & 0.712 & \\
\hline $\mathrm{X}$ gives me what I need & 0.638 & \\
\hline \multicolumn{3}{|l|}{ Process value } \\
\hline \multicolumn{3}{|l|}{ In comparison with the money, time and effort I spend... } \\
\hline $\mathrm{X}$ makes me feel good during the time I use the service & 0.761 & \multirow{3}{*}{0.818} \\
\hline $\mathrm{X}$ gives me a positive experience during the time I use the service & 0.719 & \\
\hline I have an enjoying time during the time I use the service & 0.831 & \\
\hline
\end{tabular}


TẠP CHİ PHÁT TRIỂN KH\&CN, TậP 14, SỐ Q2 - 2011

\begin{tabular}{|l|c|}
\hline I feel close to X & 0.712 \\
\hline I say positive things about X & 0.717 \\
\hline I recommend X to others & 0.687 \\
\hline I encourage friends and relatives to choose X & 0.726 \\
\hline I come back to X when I need this service in the future & 0.702 \\
\hline
\end{tabular}

The results (see Figure 1) showed that service value has a significant standardized effect on customer loyalty $(\beta=0.647, p=0.010)$. Service quality also has a significant standardized effect on service value $(\beta=0.893$, $\mathrm{p}=0.010$ ). Moreover, statistics also indicate that the indirect standardized effect of service quality on customer loyalty, via the mediation of service value, is 0.578 ( $\mathrm{p}=0.010)$. However, service quality does not affect on customer loyalty $(\beta=0.057, p=0.679)$. It indicates a full mediating model of service quality and customer loyalty via service value. It is, thus, concluded that the two hypotheses $\mathrm{H} 2, \mathrm{H} 3$ are supported by the data set in this study, while hypothesis H1 is not supported.

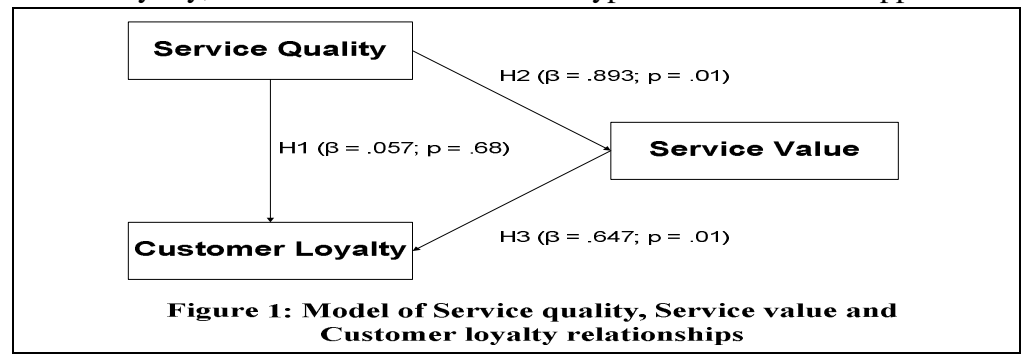

The results also indicate that two components of Service quality (second-order construct) contribute unequal to this aggregate construct. The standardized regression coefficient of Process quality is $0.889(\mathrm{p}=0.01)$, greater than Outcome quality is $0.636(\mathrm{p}=0.01)$. For Service value (second-order construct), the standardized regression coefficients of Outcome value and Process value are, respectively, $0.761 \quad(\mathrm{p}=0.01)$ and 0.637 $(\mathrm{p}=0.01)$. This also indicates the unequal contributions of the two components to Service value.

\section{DISCUSSION}

This research attempts to empirically investigate the role of service value in customer decision and choice (Sweeney et al., 1999) which only few empirical studies have investigated its antecedents and consequences (Riadh and Miguel, 2008). In addition, only few researches have tested the relationships between service quality, service value and behavioral intentions (Durvasula et al., 2004). Therefore, the findings of this research enhance the understanding of the increasing importance of service value in inseparable service industries, where the performance of the service requires the participation of customers (i.e. airlines services). It also empirical test the relationships between service value, service quality and customer loyalty. The empirical results show that, service value has a direct impact on post-purchase states of customers customer loyalty. This notices that service value is one of the key determinants of customer attitudes and behavior after consuming a service. For two components of service value, outcome value gives higher explanation of service value than process value.

This study also confirms the role of service quality as an antecedent of service value, which together explains the level of customer loyalty. In other words, service quality has indirectly significant impact on customer loyalty via service value. Theoretically this result supports the four hierarchical levels in customer's cognitive structure on the service (Zeithaml, 1988) in which service value is the higher level of service quality. Therefore, providing good service quality to customer would lead to increase customer perceived value and develop long lasting relationships with them. However, this study indicates that service quality does not directly affect customer loyalty. It supports the findings of Cronin and Taylor (1992). Moreover, with the remarkable development of Vietnamese airlines industry, passengers can choose which airlines that they assess its service is valuable to them. Consequently, 
managers may need to emphasize on both service quality and service value rather than focusing only on service quality. This notice totally supports the co-creation value concept in S-D logic perspective of Vargo and Lusch (2004).

\section{CONCLUSION}

This study provides insight in the service value substituting customer satisfaction to become a basic framework that customers use to judge the company performance. The results also confirm that solely improving service quality would not help service providers sustain their long term relationship with customers. Service quality should be see as an encouraging factor that significant impacts on customer perceived value and leads to customer loyalty.

From managerial point of view, understanding the importance of service value with two components of process and outcome value in contributing to the overall customer perceived value would help marketers know how to improve their performance. This helps service providers allocate their limited resources and efforts in delivering service, communicating service offers, and interacting with customers during the service process. In the case of domestic airlines services in Vietnam, with an acceptable price setting, it is difficult to enhance customer loyalty if only focusing on improving service quality. It is better if the efforts are based on customers' assessment of service value to adapt their expectations.

Beside the above contributions of this study, it also has a number of limitations that require future researches concern. First, the generalization of the results is not high due to data collected from only domestic airline passengers in Ho Chi Minh City. It should be conducted for passengers from all regions of Vietnam. Second, the results come from a survey of one industry, domestic service airlines, so it needs to perform for other service industries (i.e. retailing service, banking service...) to re-evaluate the results of this study. Third, the discussion of whether the service value can substitute customer satisfaction in explaining customer loyalty is only based on a model in which customer satisfaction factor does not exist. Therefore, another model including this factor should be undertaken for fully assessment.

\title{
QUAN HỆ GIŨ̉A CHÂT LƯợNG DỊCH VỤ, GIÁ TRI DỊCH VỤ VÀ LÒNG TRUNG THÀNH CỦA KHÁCH HÀNG - DỊCH VỤ HÄNG KHỐNG NỘI ĐỊA.
}

\author{
Trần Thị Phương Thảo, Phạm Ngọc Thúy \\ Trường Đại học Bách khoa, ĐHQG-HCM
}

TÓM TÁT: Trong nhiều thập kỷ qua, chất lương dịch vu được xem là cách thức tốt nhất để gia tăng lòng trung thành khách hàng thông qua việc làm cho ho cảm thấy hài lòng. Mặc dù, sư hài lòng của khách hàng được xem là yếu tố quan trọng nhất dẫn đển lòng trung thành của họ, tuy nhiên khi khách hàng hài lòng với dịch vu không phải lúc nào họ cũng trung thành với dịch vư đó. Vì thế, một số nhà nghiên cứu đề nghị rằng nên tập trung vào yếu tổ giá trị dịch vu mà khách hàng quan tâm thay vì tập trung làm hài lòng họ. Để kiểm định giả định trên, nghiên cứu này được thục hiện nhằm xem xét mối quan hệ giữa chất luợng dịch vụ, giá trị dịch vu và lòng trung thành của khách hàng. Các mối quan hệ này được kiểm định với 308 khách hàng sử dụng dịch vu hàng không nội địa Việt Nam tại thành phố Hồ Chí Minh. Kết quả nghiên cúu cho thấy hai thành phần chẩt luợng dịch vu có ảnh huơơng tích cực lên lòng trung thành của khách hàng thông qua yếu tố trung gian là giá trị dịch vụ.

Keywords: Chất luợng dịch vu, Giá trị dịch vu, lòng trung thành khách hàng, dịch vu hàng không nội địa, Việt Nam. 
[1]. Arbuckle, J.L. \& Wothke, W., Amos 4.0 User's Guide. SmallWaters Corporation, Chicago, IL., (1999).

[2]. Asubonteng, P., McCleary, K.J. and Swan, J.E. "SERVQUAL revisited: A Critical Review of Service Quality", Journal of Services Marketing, Vol. 10 No. 6, pp. 62-70, (1996).

[3]. Babakus, Emin and Gregory W.Boller, "An empirical assessment of the SERVQUAL scale", Journal of Business Research, Vol. 24, pp. 253-268, (1992).

[4]. Babin, B.J. and James, K.W., "A brief retrospective and introspective on value", European Business Review, Vol. 22 No. 5, pp. 471-478, (2010).

[5]. Babin, B.J., Darden, W.R. \& Griffin, M., "Work and or fun: measuring hedonic and utilitarian shopping value". Journal of Consumer Research, Vol 20, pp. 644-656, (1994).

[6]. Blackwell, R.D., Miniard, P.W. and Engel, J.F., Consumer Behavior, $9^{\text {th }}$ ed., Harcourt College Publishers, Ft Worth, TX, (2001).

[7]. Bolton, R.N. and Drew, J.H., "A multistage model of customers' assessments of service quality and value". Journal of Consumer Research, Vol. 17, No.4, pp. 375-384, (1991).

[8]. Boulding, W., Kalra, A., Staelin, R. and Zeithaml, V., "A dynamic process model of service quality: form expectations to behavioral intentions", Journal of Marketing Research, Vol. 30, pp. 7-27, (1993).

[9]. Brown, T.J., Gilbert A.C.Jr. and Peter, J.P., "Improving the measurement of service quality", Journal of Retailing, Vol. 69 (Spring), pp. 127-39, (1993).

[10]. Butcher, K., Beverley, S. and O'Callagham, F. "Evaluative and relational influences on service loyalty," International Journal of Service Industry Management, Vol. 12 No. 4, pp. 310-327, (2001).

[11]. Byrne, B.M., Structural Equation Modeling with AMOS. Basic Concepts, Applications and Programming. Lawrence Erlbaum Associtaes Publishers, Mahwah, NJ, (2001)
[12]. Chang, T.Z., and Wildt, A.R., "Price, product information, and purchase intention: An empirical study". Journal of the Academy of Marketing Science, Vol. 22, pp. 16-27, (1994).

[13]. Cooil, B., Keiningam, T., Aksoy, L. and Hsu, M., "A longitudinal analysis of customer satisfaction and share of wallet: investigating the moderating effect of customer characteristics", Journal of Marketing, Vol. 71 No. 1, pp. 67-83, (2007).

[14]. Cronin, J.J., \& Taylor, S.A., "Measuring service quality: a reexamination and extension. Journal of Marketing, Vol.56, pp. 55-68, (1992).

[15]. Cronin, J.J., Brady, M.K., and Hult, T.M., "Assessing the effects of quality, value and customer satisfaction on customer behavioral intentions in service environments", Journal of Retailing, Vol.76 No.2, pp.193-218, (2000).

[16]. Cronin, J.J.Jr. and Steven A.T., "Measuring service quality: a reexamination and extension", Journal of Marketing, Vol. 56 (July), pp. 55-68, (1992).

[17]. Frondizi, R., What is value?, $2^{\text {nd }}$ ed., Open Court Publishing Company, LaSalle, II, (1971).

[18]. Gallarza, M.G. and Saura, I.G., "Value dimensions, perceived value, satisfaction and loyalty: an investigation of university students' travel behavior", Tourism Management, Vol. 27 No. 3, pp. 420-436, (2006).

[19]. Gan, C., Cohen, D., Clemes, K. and Chong, E., "A survey of customer retention in the new zealand banking industry", Banks and Bank Systems, Vol. 1, No.4, pp. 83-99, (2006).

[20]. Gremler, D. and Brown, S.W., "Service quality: its nature, importance and implications", in "technology, service quality, and customer loyalty in hotels: Australian managerial perspectives", Lee et al (2003), Journal of managing service quality, Vol. 13 No. 5, pp. 423-432, (1997).

[21]. Gronroos, C., "Service logic revisited: who create value? and who co-create?", 
European Business Review, Vol. 20 No. 4, pp. 298-314, (2008).

[22]. Gronroos, C., "The perceived service quality concept - A mistake? Managing Service Quality, Vol.11, pp. 150-152, (2001).

[23]. Gronroos, C., Service Management and Marketing: Managing the Moments of Truth in Service Competition. Lexington, MA: Lexington Books, (1990).

[24]. Hair, J.F., Black, W.C., Babin, B.J., Anderson, R.E. and Tatham, R.L., Multivariate Data Analysis, $6^{\text {th }}$ ed., Pearson Prentice-Hall, Englewood Cliffs, NJ, (2006).

[25]. Jen, W. and Hu, K-C., "Application of perceived value model to identify factors affecting passengers' repurchase intentions on city bus: a case of the Taipei metropolitan area", Transportation, Vol.30 No.3, pp. 307-327, (2003).

[26]. Kashyap, R. and Bojanic, D.C., "A Structural Analysis of Value, Quality, and Price Perceptions of Business and Leisure Travelers", Journal of Travel Research, Vol.39 No.1, pp.45-5, (2000).

[27]. Khalifa, A.S., "Customer Value: A Review of Recent Literature and An Integrative Configuration", Management Decision, Vol. 42, No.5, pp. 645-666, (2004).

[28]. Kline, R.B., Principles and Practice of Structural Equation Modeling, Guilford Press, New York, NY, (1998).

[29]. Kotler, P., Marketing Management, Millenium, Prentice-Hall, Upper Saddle River, NJ, (2000).

[30]. Lee, $M$ and Cunningham, L.F., "Customer Loyalty in the Air Industry". Transportation Quarterly, Vol.50 No. 2, pp. 57-72, (1996).

[31]. Lee, Y.K., Lee, Y., Lee, K.A., Park, D.H. and Moon, H., "Exploring the role of service value in the relationshipbbetween service quality and customer satisfaction", International Journal of Hospitability and Tourism Administration, Vol.15 No.1, pp.67-86, (2004).

[32]. Lee, Y.K., Park, K.H., Park, D.H., Lee, K.A and Kwon, Y.J., "The relative impact of service quality on service value, customer satisfaction, and customer loyalty in a korean family restaurant context", International Journal of Hospitability and Tourism Administration, Vol.6 No.1, pp.2751, (2005).

[33]. Ngo, L.V. and O'Cass, A., "Value creation architecture and engineering - A business model encompassing the firmcustomer dyad", European Business Review, Vol. 22 No. 5, pp. 496-514, (2010). [34]. Oliver, R.L., "Whence customer loyalty?", Journal of Marketing, Vol. 63, Special Issue, pp. 33-44, (1999).

[35]. Parasuraman, A. and Grewal, D., "The impact of technology on the quality-valueloyalty chain: a research agenda", Journal of the Academy of Marketing Science, Vol. 28 No. 1, pp. 168-174, (2000).

[36]. Parasuraman, A., Zeithaml, V.A. and Berry, L.L., "SERQUAL: A multiple-item scale for measuring consumer perceptions of service quality", Journal of Retailing, Vol. 64, No. 1, pp. 12-40, (1988).

[37]. Petrick, J.F., "Development of a multi-dimensional scale for measuring the perceived value of a service", Journal of Leisure Research, Vol. 34 No. 2, pp. 19934, (2002).

[38]. Pleshco, L.P. and Baqer, S.M., "A preliminary study of the relationships among consumer satisfaction, loyalty, and market share in health club consumers", Proceeding of The Academy of Marketing Studies, Vol. 13 No. 1, pp. 51-7, (2008).

[39]. Riadh, L. and Miguel, M., "Perceived service quality, perceived value and recommendation: a study among Canadian public library users", Library Management, Vol. 29, Iss: 4/5, pp. 352-366, (2008).

[40]. Shan, C.L., Sunita, B., Jay, K., "Technology, service quality, and customer loyalty in hotels: Australian managerial perspectives" Managing Service Quality, Vol. 13 Iss: 5, pp.423 - 432, (2003).

[41]. Sirdeshmukh, D., Singh, J., \& Sabol, B., "Consumer Trust, Value, and Loyalty in Relational Exchanges", Journal of Marketing, Vol. 66, pp. 15-37, (2002).

[42]. Sweeney, J.C., Soutar, G.N. and Johson, L.W., "The role of perceived risk in the quality-value relationship: a study in a 
retail environment", Journal of Retailing, Vol.75 No.1, pp.77-105, (1999).

[43]. Woodruff, R.B., "Customer value: the next source for competitive advantage", Journal of the Academy, Vol.25 No.2, pp.139-53, (1997).

[44]. Zeithaml, V., "Consumer perceptions of price, quality and value: a means-end synthesis of evidence", Journal of Marketing, Vol. 52 No. 3, pp. 2-2, (1988).

[45]. Zeithaml, V., Berry, L. and Parasuraman, A., "The behavioural consequences of service quality", Journal of Marketing, Vol. 60 No 2, pp. 31-46, (1996). 